THE CANADIAN JOURNAL OF AUTISM EQUITY

LA REVUE CANADIENNE DE L'ÉQUITÉ EN MATIÈRE D'AUTISME

\begin{tabular}{l|l|l} 
VOLUME 1 & ISSUE 1 & APRIL 2021
\end{tabular}

\title{
Over and Over and Over: A Continued Call for Autistic Voices
}

Ryan B. Collis, York University, Canada 
CANADIAN JOURNAL

OF AUTISM EQUITY

REVUE CANADIENNE DE L'ÉQUITÉ

EN MATIÈRE D'AUTISME

\title{
Over and Over and Over: A Continued Call for Autistic Voices
}

\author{
Ryan B. Collis 1 (i)
}

\begin{abstract}
As an Autistic student in a master's degree, I focused on the way expertise is understood. I was specifically interested in how policy decisions in education were made without Autistic involvement. I looked at the literature that was used to make these decisions and interviewed Autistic people as to their thoughts on who should be considered experts when it comes to autism. I

found that policy was driven by experts who had little to no direct experience with autism or Autistics and who had no personal connections to the approaches they recommended. I argue that Autistic people must be involved in research design, execution, implementation, dissemination, and policy decisions.

Résumé

En tant qu'étudiant autiste en train d'effectuer une maîtrise, je me suis concentré sur notre compréhension de la notion d'expertise. Je m'intéressais plus particulièrement à la manière dont les décisions politiques en matière d'éducation étaient prises sans la participation des personnes autistes. J'ai étudié les ouvrages utilisés pour prendre ces décisions et j'ai interrogé des personnes autistes pour savoir qui, selon elles, devait être considéré comme

un(e) expert(e) en matière d'autisme. J'ai découvert que les politiques

étaient façonnées par des experts qui avaient peu ou pas d'expérience directe avec l'autisme et les personnes autistes, et qui n'avaient pas souvent des liens personnels avec les approches qu'ils recommandaient. Je soutiens

que les personnes autistes doivent être impliquées dans la conception, l'exécution, la mise en œuvre et la diffusion de la recherche, ainsi que dans les décisions politiques.
\end{abstract}

\author{
Keywords \\ Representation, Policy \\ Mots clés \\ Représentation, Politique
}

1 York University, Canada 
I will always remember how to spell the word 'tender'. The word was one of several I would be tested on in class, somewhere around Grade 5. My mother would quiz me over and over and over before these tests, and I still remember her sounding out the word, adding a syllable to emphasize that the second letter was an ' $e$ ' and not an ' $a$ '. "Tah-End-Der". Over and over and over. We would do this every week. On Fridays, all the students were given a strip of paper, the teacher read out that week's words for us to write out, and then we would pass our strip to someone else to mark as the teacher put the correct spelling on the board. Then, inundated by disappointment, I would take my strip of paper home to show my parents that I managed to fail yet another test. The education system did not train my teachers to look for the patterns I was exhibiting - I had nearly illegible handwriting, serious spelling issues, a horribly messy desk and no interventions created to assist me. This despite having the ability to read well above grade level. It was not until Grade 7 that I was diagnosed with dyslexia and dysgraphia. It was not until I was encouraged to use a computer to write my assignments that school finally became less stressful. I started to be more successful.

I had no additional problems until university when my spelling and handwriting threatened to derail me. While working on my first degree, I was fortunate that the Computer Science and Information Technology Undergraduate Program Director recognized my problems and encouraged me to go to Disability Services. It was here that a cursory examination of the poor muscle tone in my wrists and weak grip entitled me to accommodations. While access to a note taker (who was given unlimited access to the photocopier to provide me with a copy of their notes) was helpful, it was access to a computer for exams that was the most valuable. For three degrees, I was a student with learning disabilities, and I learned to cope.

After my son's autism diagnosis, I started to understand things that I had done as a child, all pointed in one direction - autism. The pulling at the heel of my socks until they tore; tearing out the tags from my shirts; throwing up when the dentist touched my tongue with the gritty polishing compound; emotional outbursts; eating the same lunch every day for decades; even the way I played with my toys or ran around watching TV after school. I was fortunate that my wife's health insurance covered the bulk of my private assessment, which I used (along with other documentation) to register with Disability Services when I went to do my fourth degree, my second Honours Bachelor of Science.

As a student in the Department of Science and Technology Studies (STS), in the Faculty of Science at York University, I became interested in the sociology of expertise, especially the work of Harry Collins. Collins (2014) questions, "who is an expert, why, and how do we know?" Besides Collins (2014), other STS authors also looked at how AIDS patients (Epstein, 1995), sheep farmers (Collins \& Evans, 2002), and scallop fishermen (Callon, 1986) were experts in fields with practical experience and yet had to deal with scientists who felt that their theoretical knowledge was the only form of understanding that deserved to be considered knowledge.

It was also around this time that I joined Twitter. I attended a conference and was asked by the department to Tweet about it. As a result, I encountered disability activists and Autistic activists on Twitter for the first time: people like @AnnMemmott, @ekverstania, @drstevenkapp and @NeuroClastic. Because of what I was studying, the discussions on the exclusion of Autistic voices in decision making and policy caught my eye. I needed a topic for my fourth-year thesis and decided to investigate something I had read - that Ontario autism policies had little to no Autistic input in their 
design.

One of the first policy documents I looked at was the report of The Ministers' Autism Spectrum Disorders Reference Group (Ministers' Autism Spectrum Disorders Reference Group , 2007) and the biographies of the members of the group (McGuinty Government Helping Students With Autism Reach Their Full Potential, 2006). When I examined the list of members of this group, I found two parents of disabled people (only one of an Autistic person), two professors of "special education" (a catch-all phrase for many different types of non-traditional learners), and eight people who had worked in some way with disabled people. Three of these people had previously been on the Minister's Advisory Council on Special Education for ten, nine, and six years, respectively. While these people had lots of experience in treating Autistics and advising Ministers, none of them were Autistic. No other identity group would accept having a policy about them decided without representation. We have to ask why this is considered appropriate for autism or disability in general. I found in the report what I had heard from people on Twitter - that only one form of intervention was being recommended, that the opinions of Autistic people were not being considered and that many Autistic people were against that intervention.

Applied Behaviour Analysis (ABA) and Intensive Behavioral Intervention (IBI) were the only treatments listed in the glossary of the report (see Appendix B: Glossary of Terms (Ministers' Autism Spectrum Disorders Reference Group, 2007, pp. 62, 65). No other interventions were included. As a result of this report, the Ontario Ministry of Education issued Policy/Program Memorandum No. 140 (PPM 140): Incorporating Methods of Applied Behaviour Analysis (ABA) Into Programs For Students With Autism Spectrum Disorders (ASD) (Government of Ontario, 2007). This document mandated the use of ABA (where appropriate) in all schools in Ontario. It noted that "[t]his memorandum has been informed by recommendations of the Report of the Minister's Autism Spectrum Disorders Reference Group." Yet this “evidence-based” treatment was supported by only one citation in PPM 140, Perry \& Condillac (2003). Both of the authors are Behaviour Analysts and teachers of ABA practitioners, but they did not declare that as a potential conflict of interest in their report on Behaviour Analysis. Bottema-Beutel et al. have found such conflicts of interest common in research on autism intervention (Bottema-Beutel et al., 2021; Dawson \& Fletcher-Watson, 2021).

While PPM 140 made ABA the standard approach in schools based on the report, that same report also found that "Individualized programs conceptualized to meet the needs of the individual student" and "[s]tructured environment - structure of the school environment and activities are organized, predictable and understandable for the student" have "been found ... as important and, in some cases, may be more important to child outcomes than the use of any specific technique" (Ministers' Autism Spectrum Disorders Reference Group, 2007, p. 21). This language directly contradicts the decision to mandate a single approach mandatory. Additionally, the report goes on to say that:

... it is not true that all children need exactly the same type of treatment. Not all children need incredibly intensive intervention that takes up between 20-40 hours a week. Some children do respond, but other children do not respond to even that level of intensity and can do just as well with 
less intensive forms of treatment that are carried out in more naturalistic settings. We do not know the relative proportion of those types of children but there is now more and more scientific evidence showing us that different forms of intervention can be adapted to different types of Autism Spectrum Disorder. (Ministers' Autism Spectrum Disorders Reference Group, 2007, p. 22)

This raised the question for me: how does a report that includes a recommendation that "different forms of intervention can be adapted" and noted that predictable and understandable environments were more important than the specific intervention used become an argument that only one form of 'treatment' should receive provincial funding and support? And how does the report not cite any research that calls into question that approach (e.g., Kohn, 2020; Kupferstein, 2018; Rodgers et al., 2020; Sandbank et al., 2020; Sandoval-Norton \& Shkedy, 2019; Shea V, 2005; The Department of Defense Comprehensive Autism Care Demonstration Annual Report, 2019; The Department of Defense Comprehensive Autism Care Demonstration Annual Report, 2020; Wilkenfeld \& McCarthy, 2020)? I set out examine how something under the label "evidence-based" was made policy against the wishes of Autistics (as represented by many detractors on social media) and wrote a fourth-year honours thesis called "Negotiating the Meaning of 'Evidence Based' Autistic Programming" (Collis, 2019) where I interviewed Autistic people on their thoughts around treatments and interventions, and on who was considered an expert in autism. I was not the first researcher to ask these kinds of questions. Damian Milton also uses Collins and Evans' work (Collins, 2004, 2010, 2011; Collins et al., 2006; Collins and Evans, 2007) to critique how autism studies often ignore the lived experience and expertise of Autistic people in favour of input from relatives of Autistic people (Milton, 2014; Milton et al., 2014). Others are using Community Based Participatory Research (CBPR) to work with Autistic people to ask the research questions they want answered and together they cooperate on how the research is designed, carried out, and disseminated (Nicolaidis et al., 2019). For Autistic research to be valuable to Autistic people and their supporters, the research must be guided by their priorities, designed with their input, and shared so they can use it to improve their lives (Collis, 2019; Milton et al., 2014). It is research springing from such sources that must be the basis of policy decisions. We would not accept a report on the education of girls, based on scant research with potential conflicts of interest, written by authors whose only connection with women is that they have daughters or wives or worked with women in the past. We must change the attitude that policy can be made without input from Autistic people when those decisions directly affect their lives and are better informed by their lived expertise.

ORCID iD

Ryan Collis (iD https://orcid.org/0000-0001-6144-2345

\section{References}

Bottema-Beutel, K., Crowley, S., Sandbank, M., \& Woynaroski, T. G. (2021). Research Review: Conflicts of Interest (COIs) in autism early intervention research - a meta-analysis of COI influences on intervention effects. Journal of Child Psychology and Psychiatry, 62(1), 5-15. https://doi.org/ 10.1111/jcpp. 13249

Callon, M. (1986). Some Elements of a Sociology of Translation: Domestication of the scallops and the fishermen of St Brieuc Bay. In J. Law (Ed.), Power, Action and Belief. Routledge.

Collins, H. (2014). Are we all scientific experts now? Polity.

Collins, H., \& Evans, R. (2002). The Third Wave of Science Studies: Studies of Expertise and Experience. Social Studies of Science, 32(2), 235-296. https://doi.org/10.1177/0306312702032002003 
Collis, R. (2019). Negotiating the Meaning of 'Evidence Based' Autistic Programming [Undergraduate Thesis, York University]. https: / / www.mrcollis.ca/research/negotiating-the-meaning-of-evidence-basedautistic-programming

Dawson, M., \& Fletcher-Watson, S. (2021). Commentary: What conflicts of interest tell us about autism intervention research-a commentary on Bottema-Beutel et al. (2020). Journal of Child Psychology and Psychiatry, 62(1), 16-18. https://doi.org/10.1111/jcpp.13315

Epstein, S. (1995). The Construction of Lay Expertise: AIDS Activism and the Forging of Credibility in the Reform of Clinical Trials. Science, Technology, \& Human Values, 20(4), 408-437. https: //doi.org/ 10.1177/016224399502000402

Government of Ontario. (2007). Policy/Program Memorandum No. 140. Ontario Ministry of Education. http: / / www.edu.gov.on.ca/extra/eng/ppm/140.html\#1

Kohn, A. (2020, January 29). Autism and Behaviorism: New Research Adds to an Already Compelling Case Against ABA. National Education Policy Center. https://nepc.colorado.edu/blog/autism-andbehaviorism

Kupferstein, H. (2018). Evidence of increased PTSD symptoms in autistics exposed to applied behavior analysis. Advances in Autism, 4(1), 19-29. https://doi.org/10.1108/AlA-08-2017-0016

McGuinty Government Helping Students With Autism Reach Their Full Potential. (2006, September 20). Ontario Newsroom. https: / /news.ontario.ca/archive/en/2006/09/20/McGuinty-GovernmentHelping-Students-With-Autism-Reach-Their-Full-Potential.html

Milton, D. (2014). Autistic expertise: A critical reflection on the production of knowledge in autism studies. Autism, 18(7), 794-802. https: // doi.org/10.1177/1362361314525281

Milton, D., Mills, R., \& Pellicano, E. (2014). Ethics and Autism: Where is the Autistic Voice? Commentary on Post et al. Journal of Autism \& Developmental Disorders, 44(10), 2650-2651. https://doi.org/ $10.1007 / \mathrm{s} 10803-012-1739-\mathrm{x}$

Ministers' Autism Spectrum Disorders Reference Group. (2007). Making a Difference for Students with Autism Spectrum Disorders in Ontario Schools. Queen's Printer for Ontario.

Nicolaidis, C., Raymaker, D., Kapp, S. K., Baggs, A., Ashkenazy, E., McDonald, K., Weiner, M., Maslak, J., Hunter, M., \& Joyce, A. (2019). The AASPIRE practice-based guidelines for the inclusion of autistic adults in research as co-researchers and study participants. Autism, 23(8), 2007-2019. https:// doi.org/10.1177/1362361319830523

Perry, A., \& Condillac, R. (2003). Evidence-Based Practices for Children and Adolescents With Autism Spectrum Disorders: Review of the Literature and Practice Guide. Children's Mental Health Ontario.

Rodgers, M., Marshall, D., Simmonds, M., Le Couteur, A., Biswas, M., K, W., D, R., S, P., \& R, S. L. \& H. (2020). Interventions based on early intensive applied behaviour analysis for autistic children: A systematic review and cost-effectiveness analysis. Health Technology Assessment, 24(35). https:// doi.org/10.3310/hta24350

Sandbank, M., Bottema-Beutel, K., Crowley, S., Cassidy, M., Dunham, K., Feldman, J. I., Crank, J., Albarran, S. A., Raj, S., Mahbub, P., \& Woynaroski, T. G. (2020).

Project AIM: Autism intervention meta-analysis for studies of young children. Psychological Bulletin, 146(1), 1-29. http://dx.doi.org.ezproxy.library.yorku.ca/10.1037/bul0000215

Sandoval-Norton, A. H., \& Shkedy, G. (2019). How much compliance is too much compliance: Is long-term ABA therapy abuse? Cogent Psychology, 6(1), 1641258. https://doi.org/ 10.1080/23311908.2019.1641258

Shea V. (2005). A Perspective on the Research Literature Related to Early Intensive Behavioral Intervention (Lovaas) for Young Children with Autism. Communication Disorders Quarterly, 26(2), 102-111.

The Department of Defense Comprehensive Autism Care Demonstration Annual Report. (2019). [Report to the Committees on Armed Services of the Senate and House of Representatives]. http: / /health. mil/ Reference-Center/Congressional-Testimonies/2019/06/10/Annual-Report-on-Autism-CareDemonstration-Program

The Department of Defense Comprehensive Autism Care Demonstration Annual Report. (2020). [Report to the Committees on Armed Services of the Senate and House of Representatives]. https:// therapistndc.org/wp-content/uploads/2020/08/Annual-Report-on-Autism-Care-DemonstrationProgram-for-FY-2020.pdf

Wilkenfeld, D. A., \& McCarthy, A. M. (2020). Ethical Concerns with Applied Behavior Analysis for Autism Spectrum “Disorder.” Kennedy Institute of Ethics Journal, 30(1), 31-69. 